\title{
Implementasi Media Pembelajaran Interaktif Pada Materi Trigonometri Untuk SMA
}

\author{
Fera Damayanti \\ STT-Harapan \\ feradamayantii@gmail.com
}

\begin{abstract}
Abstrak
Trigonometri adalah tofik matematika untuk siswa sekolah menengah atas yang memiliki tingkat kesulitan karena siswa harus mengingat semua tentang sudut dan fungsi trigonometri seperti sinus, kosinus dan tangen. Disni ada dua alasan mengapa guru seharusnya menyiapkan strategi pembaharuan dalam pengeajaran. Pertama, terdapatnya kepercayaaan secara umum bahwa matematika adalah pelajaran yang sulit, kedua, setiap siswa memiiki tingkat pemahaman yang berbeda dalam memahami materi. Aplikasi media pembelajaran trigonometri membuat belajar trigonometri menjadi lebih menyenangkat karena tampilannya yang interaktif dan menarik sehingga menarik minat siswa dalam belajar trigonometri dan serta dapat meningkatkan kemampuan siswa dalam memahami pelajaran trigonometri.
\end{abstract}

\section{Pendahuluan}

Belajar merupakan suatu proses yang kompleks yang terjadi pada diri sendiri setiap orang sepanjang hidupnya. Proses belajar terjadi karena adanya interaksi antara seseorang dengan lingkungannya. Pelaksanaan pembelajaran yang baik hendaknya dikembangkan berdasarkan prinsip pengembangan dan pelaksanaan kurikulum. Pengembangan Kurikulum Tingkat Satuan Pendidikan diharapkan sesuai dengan kebutuhan peserta didik dan masyarakat, beragam, terpadu serta tanggap terhadap perkembangan ilmu pengetahuan, teknologi dan seni (Umar dkk, 2013). Sedangkan prinsip pelaksanaan KTSP dengan menggunakan multistrategi dan multimedia, sumber belajar, dan tekologi yang memadai serta memanfaatkan lingkungan sekitar sebagai sumber belajar.

Masalah umum yang sering dihadapi oleh peserta Sekolah Menengah Atas adalah masih cukup banyak yang belum dapat mencapai prestasi belajar yang memuaskan dibidang matematika khususnya materi trigonometri. Disamping itu sampai saat ini anggapan di lapangan pelajaran matematika masih merupakan mata pelajaran yang cendurung kurang manarik dan sukar bagi siswa.

Demi mencapai prestasi belajar yang memuaskan tersebut dengan sistem pendidikan yang makin maju dan didukung perkembangan teknologi yang semakin pesat eknologi multimedia telah menjanjikan potensi besar dalam merubah cara seseorang belajar untuk memperoleh informasi. Multimedia juga menyediakan peluang bagi pendidik untuk mengembangkan teknik pembelajaran yang lebih kreatif dan inovatif.

Media pembelajaran merupakan salah satu komponen pembelajaran yang mempunyai peranan penting dalam kegiatan belajar dan mengajar. Pemanfaatan media seharusnya juga merupakan bagian yang harus mendapat perhatian guru atau fasilitator dalam kegiatan pembelajaran. Oleh karena itu guru atau fasilitaor juga harus mempelajari bagaimana menetapkan media pembelajaran agar dapat mengefektifkan pencapaian tujuan pembelajaran dalam proses belajar mengajar.

\section{Landasan Teori \\ 2.1 Computer Assistent Instruction (CAI)}

Computer Assistent Instruction atau pembelajaran berbasis komputer adalah aplikasi komputer sebagai bagian integral dalam sistem pembelajaran terhadap proses belajar dan mengajar yang bertujuan membantu siswa dalam belajarnya, bisa melalui pola interaksi dua arah melalui terminal komputer maupun multi arah melalui pemanfaatan jaringan komputer (Risal, 2013). Pembelajaran berbasis komputer terkait langsung dengan pemanfaatan komputer dalam kegiatan pembelajran baik secara individu maupun kelompok.

\subsection{Media Pembelajaran}

Media yaitu segala sesuatu yang dapat digunakan untuk menyalurkan pesan. Pembelajaran merupakan proses komunikasi yang didalamnya terdapat sumber pesan, penerima pesan dan pesan yaitu materi pembelajaran. 
Media merupakan salah satu komponen komunikasi, yaitu sebagai pembawa pesan dari komunikasi yaitu sebagai pembawa pesan dan komunikator menuju komunikasi, proses pembelajaran mengandung lima komponen yaitu guru (komunikator), bahan pembelajran, media pembelajaran, siswa (komunikan) dan tujuan pembelajaran.

\subsection{Adobe Flash}

Adobe Flash yang sebelumnya Macromedia Flash adalah software yang banyak dipakai oleh desainer web karena mempunyai kemampuan yang lebih unggul dalam menampilkan multimedia, gabungan antara grafis, animasi, suara, serta interaktifitad user. Adobe Flash merupakan sebuah program aplikasi standart authoring tool profesional yang digunakan untuk membuat animasi vektor dan bitmap yang sangat baik untuk membuat situs web yang interaktif, menarik dan dinamis. Software ini berbasis animasi vektor yang dapat digunakan untuk menghasilkan animasi web, presentasi, game, film maupun $\mathrm{CD}$ interaktif, CD pembelajaran.

Interaksi user dalam movie flash menggunakan Actionscript, Actionscript adalah suatu bahasa pemograman yang berorientasi objek yang dipakai dalam mengembangkan pemograman interaktif secara efisien.

\subsection{Trigonometri}

Trigonometri dapat diartikan sebagai cabang ilmu matematika yang mempelajari tentang perbandingan ukuran sisi suatu segitiga apabila ditinjau dari salah satu sudut yang terdapat pada segitiga tersebut.

Pada prinsifnya trigonometri merupakan salah satu cabang ilmu yang berhubungan dengan besar sudut, dimana bermanfaat untuk menghitung ketinggian suatu tempat tanpa mengukur secara langsung sehingga bersifat lebih praktis dan efisien. Dalam penerapannya, trigonometri digunakan di bidang navigasi, pengukuraan, fotografi, fisika dan sebagainya. Sebagai contoh dalam navigasi pelayaran konsep dasar perbandingan trigonometri digunakan dalam menentukan arah dan jarak dari suatu tempat ke tempat lainnya.

\section{Perancangan Aplikasi 3.1 Gambaran Umum Aplikasi}

Aplikasi yang akan dirancang disini mengangkat materi pembelajaran trigonometri untuk sekolah menengah atas kelas X. Adapun materi yang diambil adalah pengukuran sudut, perbandingan trigonometri, identitas trigonometri, fungsi trigonometri dan grafiknya dengan menggunakan sotware Adobe Flash CS3.

\subsection{Struktur Navigasi}

Struktur navigasi merupakan hal yang paling penting dari pembuatan aplikasi pembelajaran. Karena struktur ini yang akan menjadi arah dan acuan dari aplikasi yang dibuat. Pada aplikasi pembelajaran trigonometri navigasi mempunyai rangkain cerita yang berurut dan memiliki percabangan untuk menampilkan data berdasarkan kriteria tertentu.

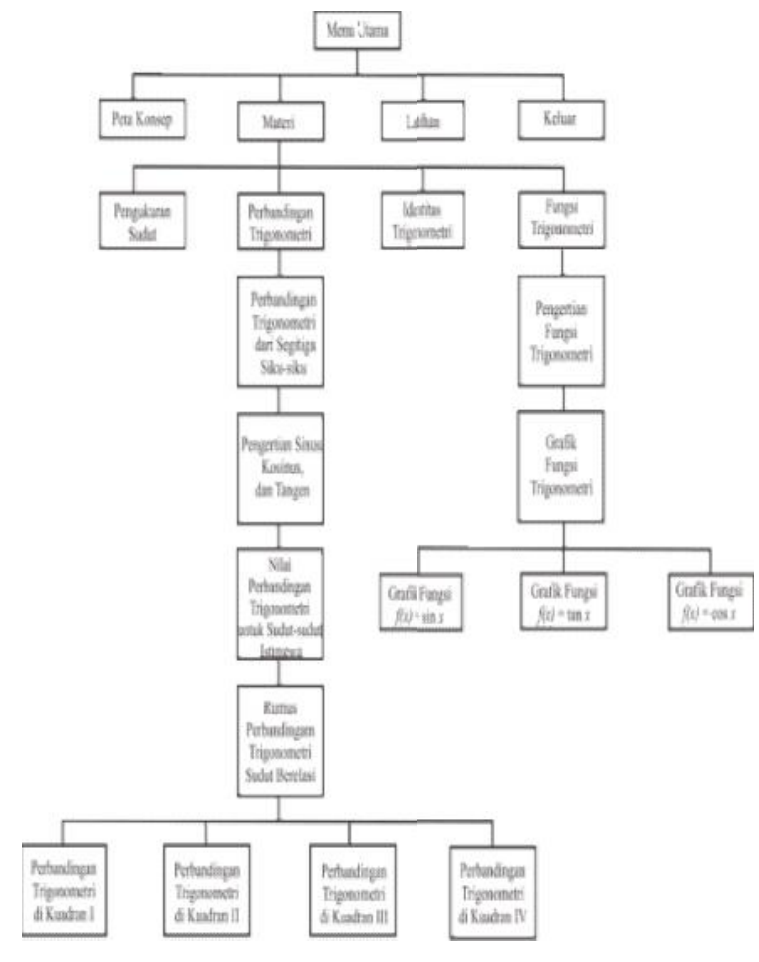
Gambar 3.1 Struktur Navigasi Aplikasi
Pembelajaran Trigonometri 


\subsection{Perancangan Storyyboard}

Storyboard adalah alur cerita atau sketsa/skenario dari tampilan suatu aplikasi pada layar secara detail. Adapun stroybord pengembangan aplikasi media pembelajaran trigonometri ini adalah sebagai berikut :

1. Aplikasi pembelajaran ini dimulai dari halaman utama, dimana pada halaman utama ini terdapat empat bua menu yaitu menu materi, latihan, peta konsep dan keluar seperti gambar 3.2.

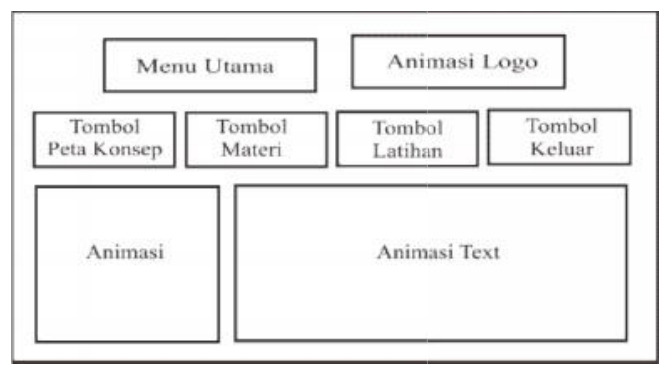

Gambar 3.2 Rancangan Tampilan Halaman Utama

2. Pada menu materi terdapat sub menu yaitu menu pengukuran sudut, menu perbandingan trigonometri, menu identitas trigonometri dan menu fungsi trigonometri dan grafiknya.

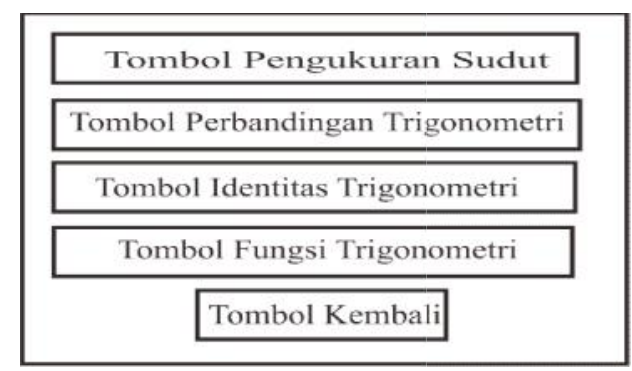

Gambar 3.3 Rancangan Tampilan Halaman Materi

3. Pada menu pengukuran sudut berisi tentang satuan pengukuran sudut dan hubungan derajat dengan radian. Pada materi satuan pengukuran sudut dijelaskan pengertian sudut dan satuan-satuan yang dipakai dalam pengukuran sudut. Sedangkan dalam materi hubungan derajat dengan radian dijelaskan cara pengubah saatuan sudut dalam radian ke derajat serta sebaliknya.

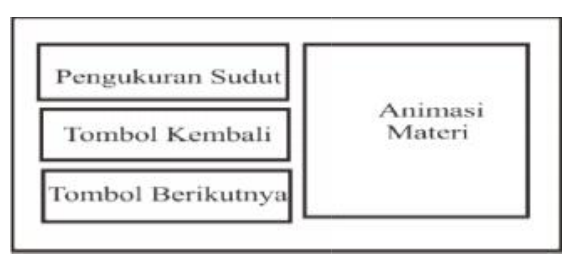

Gambar 3.4 Rancangan Menu Pengukuran Sudut

4. Untuk menu latihan merupakan soal pilihan berganda yang berkaitan dengan materi yang telah dipelajari sebelumnya.

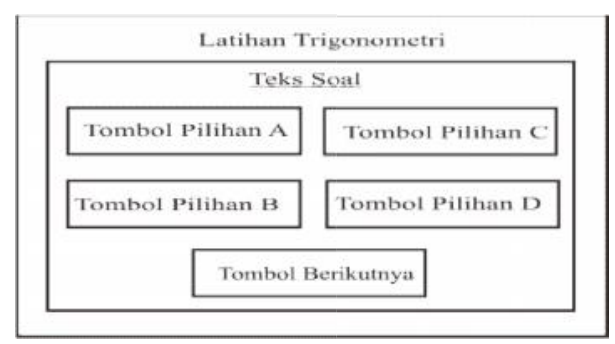

Gambar 3.5. Rancangan Menu Latihan

Untuk sub menu yang lain memiliki rancangan menu yang hampir sama, hanya berbeda di pada sub sub menu yang dimiliki setiap sub menu.

\section{Implementasi dan Pengujian 4.1 Implementsi}

Implementasi dilakukan dengan mengerjakan rancangan yang telah dibuat kedalam software yang telah ditetentukan yaitu Adobe Flash CS 3. Berikut adalah hasil implementasi rancangan kedalam program.

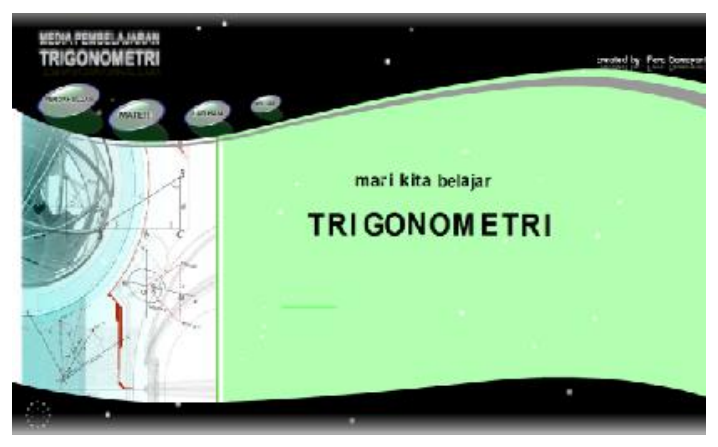

Gambar 4.1. Tampilan Menu Utama Media Pembelajaran 
Pada menu Utama terdapat menu Pendahuluan, menu Materi, menu Latihan dan menu Keluar.

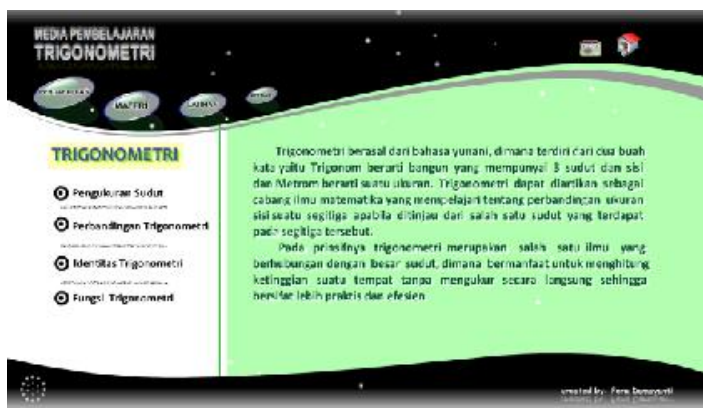

Gambar 4.2 Tampilan Menu Materi

Didalam menu materi terdapat materi-materi yang dipelajari didalam trigonometri, yang dapat diakses dengan memilih salah datu materi yang tersedia seperti gambar 4.2.

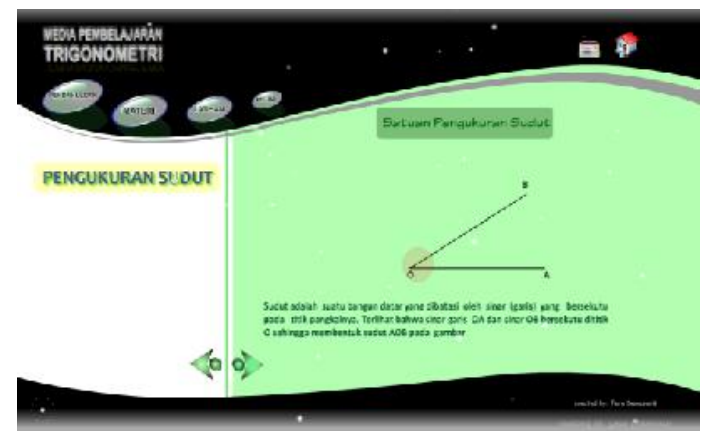

\section{Gambar 4.3. Tampilan Materi Pengukuran Sudut}

Pada gambar4.3 merupakan halaman sub menu dengan materi pengukuran sudut. Pengukuran sudut merupakan materi pertama yang diajarkan dalam trigonometri.

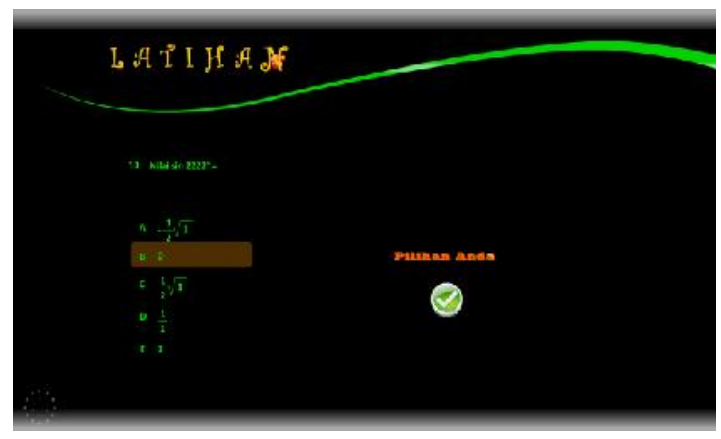

Gambar 4.4. Tampilan Latihan
Pada gambar 4.4 merupakan lembar kerja latihan yang mana soal merupakan pilihan berganda, hasil dari jawaban dapat langsung diketahui dengan adanya indikator benar ataupun salah.

\subsection{Pengujian}

Untuk proses pengujiannya mengunakan kuesioner yang diberikan kepada siswa Sekolah Menengah Atas kelas $\mathrm{X}$, yang mana hasil kuesioner tersebut dapat dipresentasikan dengan menjumlahkan seluruh jawaban koresponden. Maka dari hasil pengujian didapat bahwa aplikasi ini memiliki tingkat validitas $78 \%$ dapat digunakan dalam media pembelajaran trigonometri.

\section{Kesimpulan}

Berdasarkan hasil penelitian ini maka peneliti dapat menyimpulkan :

1. Berdasarkan hasil kuesioner mMedia pembelajaran trigonometri ini interaktif dan menarik sehingga menarik minat siswa untuk belajar trigonometri

2. Adobe Flash CS3 merupakan software yang sangat mendukung dalam pembuatan media pembelajaran interkatif, penggunaan media yang terlalu banyak sangat mempengaruhi pada proses awal media dijalankan.

3. Penelitian ini dapat dikembangkan dengan materi trigonometri yang lebih lengkap lagi yang berisikan video untuk setiap contoh kejadian.

\section{References}

[1] Didik W.S, Vincent. S, dan Stefanus. S,"Multimedia Pembelajaran Reproduksi Pada Manusia”,Jurnal Teknologi Informasi,Udinus, 2009,Vol. 5 No. 2, hlm.711-724.

[2] I Gusti Putu. A.S dan I Wayan S,'Pengembbangan Perangkat Pembelajaran Matematika Realistik Dengan Peta Konsep Pada Materi Trigonometri Di Kelas XI SMK", eJournal Program Pascasarjana Universitas Pendidikan Ganesha,2013, Vol. 2,

[3] Ilham Eka Putra,'Teknologi Media Pembelajaran Sejarah Melalui Pemanfaatan Multimedia Animasi Interaktif", TEKNOIF. STMIK Indonesia, Padang, 2013, hlm. 20-24. 
[4] Risal M. Merentek,'Pembelajaran Komputer Sarana Multimedia Dalam Pengembangan Pendidikan",Jurnal Pendidikan Dasar,UNIMA, 2012, Vol. 3,No.5, hlm. 163173.

[5] Rudi.H, Y.Tyas Catur.P,"Multimedia Pembelajaran Lithosfer Untuk SMA Kelas X',Jurnal Teknologi Informasi,Udinus, 2009, Vol. 5 No.2, hlm. 695-709.

[6] Syahrizal Dwi Putra," Desain Dan Implementasi Evaluasi Pembelajaran Berbasis Multimedia Menggunakan Flash,PHP, Daan MySQL",Jurnal Majemen Informatika, STMIK Jayakarta,2013, hlm. 1-6.

[7] Youlia Indrawaty dan M. Yusuf Bakhtiar," Implementasi Model Skenario Petri Net Pada Multimedia Interaktif Pembelajarn Kimia”,Jurnal informatika, 2013, Vol.4 No.1, hlm 48-56. 